 \\ International Journal of Social Sciences and Management
}

\section{A Rapid Publishing Journal}

ISSN 2091-2986

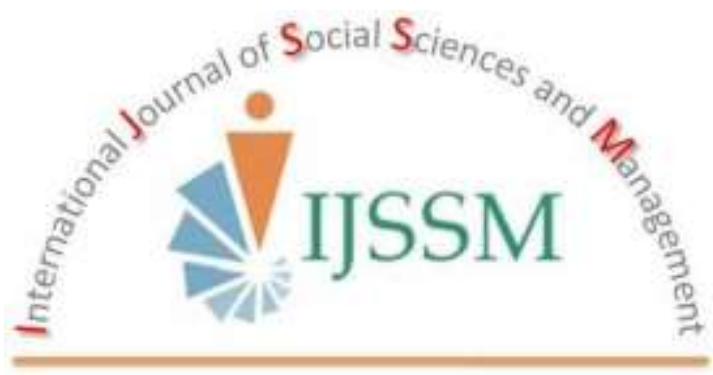

\section{Indexing and Abstracting}

CrossRef, Google Scholar, International Society of Universal Research in Sciences (EyeSource), Journal TOCs, New Jour, Scientific Indexing Services, InfoBase Index, Open Academic Journals Index (OAJI), Scholarsteer, Jour Informatics, Directory of Research Journals Indexing (DRJI), International Society for Research Activity (ISRA): Journal Impact Factor (JIF), Simon Fraser University Library, etc.

Vol-2(1) July, 2015 


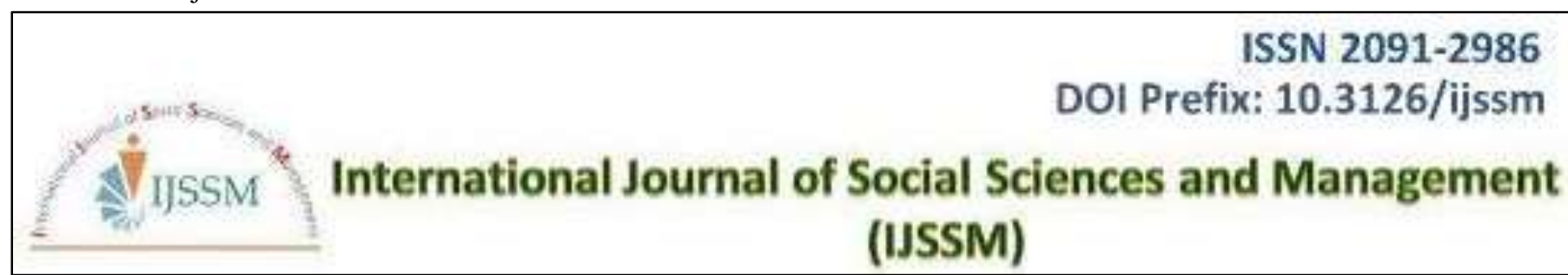

\title{
Mini Review \\ A COMPARATIVE STUDY ON PERFORMANCE OF PUBLIC AND PRIVATE TELECOMMUNICATION SECTORS WITH REFERENCE TO WIRELESS SERVICES IN ASSAM CIRCLE
}

\author{
Papori Baruah $^{1}$ and Rashmi R. Baruah ${ }^{2 *}$ \\ ${ }^{1}$ Business Administration Department, Tezpur Central University. Assam, India \\ ${ }^{2}$ Business Administration Department, University of Science \& Technology. Meghalaya, India \\ *Corresponding author email: rashmichangkakoty@gmail.com
}

\begin{abstract}
Indian Telecom Sector is one of the fastest growing domains compared to other sectors of development, which has received extensive investments, both by government as well as private players in the recent years. The prime purpose of this study was to compare the performance of Public and Private Telecommunication sector with reference to wireless services in Assam Telecom Circle. The paper tried to explore and understand the major similarities and differences existing between the public and private cellular service providers in terms of market penetration effectiveness, their subscribers' base, revenue earned by them etc. in the above mentioned Circle. National and State level data of Telecom Sector was collected on a periodic basis over time. A critical evaluation had been done with the help of Applied Analytical Research, by using facts and information already available. The result showed that there were few common factors applicable to both Public and Private Telecom Sector; however significant differences in performance are there in these sectors in Assam Circle. The key findings from this study describe that visibly the Private Sector had better performance than Public Sector in terms of few parameters considered in this study, which might indicate a possible development direction for the effectiveness of Public Sector in this Circle.
\end{abstract}

Key words: Assam Telecom Circle; Private Telecom Sector; Public Telecom Sector; Wireless subscribers' base; Wireless Market share.

\section{Introduction}

In present times, Indian Telecommunication Sector is one of the fastest growing telecom sectors in the world and it has become the second largest network in the world, next only to China. This sector is a core infrastructure industry and acts as a catalyst for overall growth of the economy. Very exponential growth of Telecom Sector in Assam Circle has been observed only in the last decade, which helped the state in its economical development. This sector has really adopted the most structural, fundamental and institutional restructuring. It has created more job opportunities, both direct and indirect, supported trade and commerce and helped in enhancing the quality of civic life in the Assam Circle.

It is believed that a $1 \%$ improvement in telecom penetration results in more than 3\% growth in GDP. According to Joshi (2014), World Bank believes that "A 10\% increase in mobile penetration increases the per capita GDP by $0.81 \%$ in the developing countries" World Bank.

\section{Assam Telecom Circle: Wireless services}

Telecom sector in India has registered an exponential growth over last two decades. Most fundamental and structural restructuring has taken place in Indian Telecom Sector just after the liberalization. The country is divided into multiple zones for effective performance and proper management of this sector. These zones are called 'Circles', roughly along state boundaries. The Assam circle is formed approximately along the boundaries of State of Assam. This circle is fully covered by Assam Licensed Service Area. Telecom industry is growing at a rapid pace in Assam Circle, as the demand is increasing day by day. Over the last decade, the circle has witnessed substantial growth related to subscriber base in both rural and urban areas, especially in wireless segment.

\section{Public and Private sector in Assam Telecom Sector}

The Telecom Sector of India has undergone a dramatic transformation from the government monopoly to a competitive environment after liberalization, where multiple private players could enter and started giving services to customers. The wireless telecommunications system in India is the second largest in the world and it was thrown open to private sector in 1990s. The Assam Telecom Circle consists of both Government and Private telecom companies. The joint effort of Government and private players of this sector has improved a lot and on its way of growth and development. These companies run local and long distance telephone services and there is a very healthy competition among the companies existing in Assam Circle. This competition is one of the main causes of dropping the 
prices and hence the call rates in the circle are quite low. According to Kumar \& Uma (2013), with the increase in network coverage and competition being very tough, has resulted in decline of tariffs acting as catalyst for the growth in subscriber base.

\section{Major players in Assam Telecom Circle}

The Assam circle has three types of telecom players presently in the year 2014, they are-

1. State Owned Company/ Public Sector Undertaking

- Bharat Sanchar Nigam Limited, (BSNL).

2. Private Indian Owned Company--

- Reliance Telecom Limited.

- Idea Cellular Limited.

3. Private companies with majority stake by Foreign Investors

- Bharti Airtel Limited.

- Dishnet wireless Limited (AIRCEL).

- Vodafone Spacetel Limited.

\section{Literature Review}

Kumar and Uma (2013), attempted to compare the public and private cellular service providers in Karnataka state and they explained that private cellular operators are proved to be the favorites of mobile users. During the study it was also revealed that BSNL is fading away from the minds of mobile and telephone users.

According to Yadav (2014), as the market matures and competition intensifies, wireless telephone service operators will have to differentiate their corporate strategies with respect to customer focus, personalization, marketing and delivering tailored offers. He concluded that during last few years most of the private telecom service providers have shown better performance than their public sector rivals in terms of network coverage, innovation, revenue share etc.

According to Verma et. all (2012), private sector Indian Organizations are doing much more better than Indian public sector organizations as private sector organizations have better team empowerment and so teamwork and team effectiveness compare to their counterparts.

Goel and Rekhi (2013), given their views that the public sector banks are not as profitable as private sector banks are, in terms of return on assets, return on equity etc.

However,Chaudhary (2014), concluded in his study of performance comparison of private sector and public sector banks in India, most of the new private sector banks have shown better performance than their public sector counterparts.

Vazifehdost \& Rahmani (2013), said that the private sector nurse were the most contented with their supervisor-nurse relationship and teamwork, so can give better performance.

\section{Objectives of the Study}

The objectives of the study are:

1. To review the performance of cellular operators of Public and Private Telecommunication sectors in Assam Circle.

2. To make a comparative study on the performance of these telecommunication players in Assam Circle.

3. To provide suggestions to cellular operators based on the key finding of the research.

\section{Methodology}

It is based on secondary data collected from the Department of Telecommunication, Telecom Regulatory Authority of India, Ministry of Communication, the reports from Government of India, research papers, articles and other sources. In order to study the specified objectives, statistical tools like year-wise Percentage of market share of different service providers, annual growth rate, percentage and ratio of different segments were calculated.

\section{Discussion}

This study has been drafted to compare the performance of service providers of public sector and private sector telecommunication in Assam Circle. Here, the researcher has also discussed about- different Service providers of Assam Circle, Wireless subscribers' base, Market share of these service providers, Market positions and their Gross revenues etc. It has been seen that the Telecom Circle of Assam has registered a phenomenal growth during the last few years, propelled largely by the unprecedented growth of the mobile telephony and infrastructure, which not only is beneficial for the telecom sector but has a multiplier effects over the entire economy of the circle.

\section{Wireless subscribers' base of Public and Private Telecom sector in Assam Circle}

The many fold growth of wireless subscribers can be seen in Assam Circle, where the Private sector has the maximum subscribers' base today. As on January 2015, out of $1,65,47,781$ total number of subscribers in the circle, Private sector has $1,52,76,124$ compared to $12,71,657$ of Public sector's subscribers. In this case, the ratio of publicprivate sector is almost 1:12 (Table 1). 
P. Baruah and R.R. Baruah (2015) Int. J. Soc. Sci. Manage. Vol-2, issue-3: 188-192

Table 1: Wireless subscribers' base of public and private sector

\begin{tabular}{|l|l|l|l|l|l|l|l|l|l|l|}
\hline S.N. & $\begin{array}{l}\text { Operators } \\
\text { in Assam }\end{array}$ & $\begin{array}{l}\text { June'11 } \\
\text { (Number) }\end{array}$ & $\begin{array}{l}\text { Jan'12 } \\
\text { (Number) }\end{array}$ & $\begin{array}{l}\text { Jan'13 } \\
\text { (Number) }\end{array}$ & $\begin{array}{l}\text { Apr'13 } \\
\text { (Number) }\end{array}$ & $\begin{array}{l}\text { Jan'14 } \\
\text { (Number) }\end{array}$ & $\begin{array}{l}\text { Mar'14 } \\
\text { (Number) }\end{array}$ & $\begin{array}{l}\text { Jun'14 } \\
\text { (Number) }\end{array}$ & $\begin{array}{l}\text { Sep'14 } \\
\text { (Number) }\end{array}$ & $\begin{array}{l}\text { Jan'15 } \\
\text { (Number) }\end{array}$ \\
\hline 1. & $\begin{array}{l}\text { Public } \\
\text { Sector }\end{array}$ & $15,27,532$ & $16,04,587$ & $12,30,918$ & $12,28,238$ & $12,53,553$ & $12,80,869$ & $13,09,794$ & $12,98,949$ & $12,71,657$ \\
\hline 2. & $\begin{array}{l}\text { Private } \\
\text { Sector }\end{array}$ & $1,11,61,692$ & $1,24,04,896$ & $1,30,43,093$ & $1,33,04,421$ & $1,39,57,006$ & $1,39,97,339$ & $1,42,56,405$ & $1,46,08,251$ & $1,52,76,124$ \\
\hline Total & & $1,26,89,224$ & $1,40,09,483$ & $142,74,011$ & $1,45,32,659$ & $1,52,10,559$ & $1,52,78,208$ & $1,55,66,199$ & $1,59,07,200$ & $1,65,47,781$ \\
\hline
\end{tabular}

Source: TRAI Press Release, 2011, 2012, 2013, 2014 and 2015

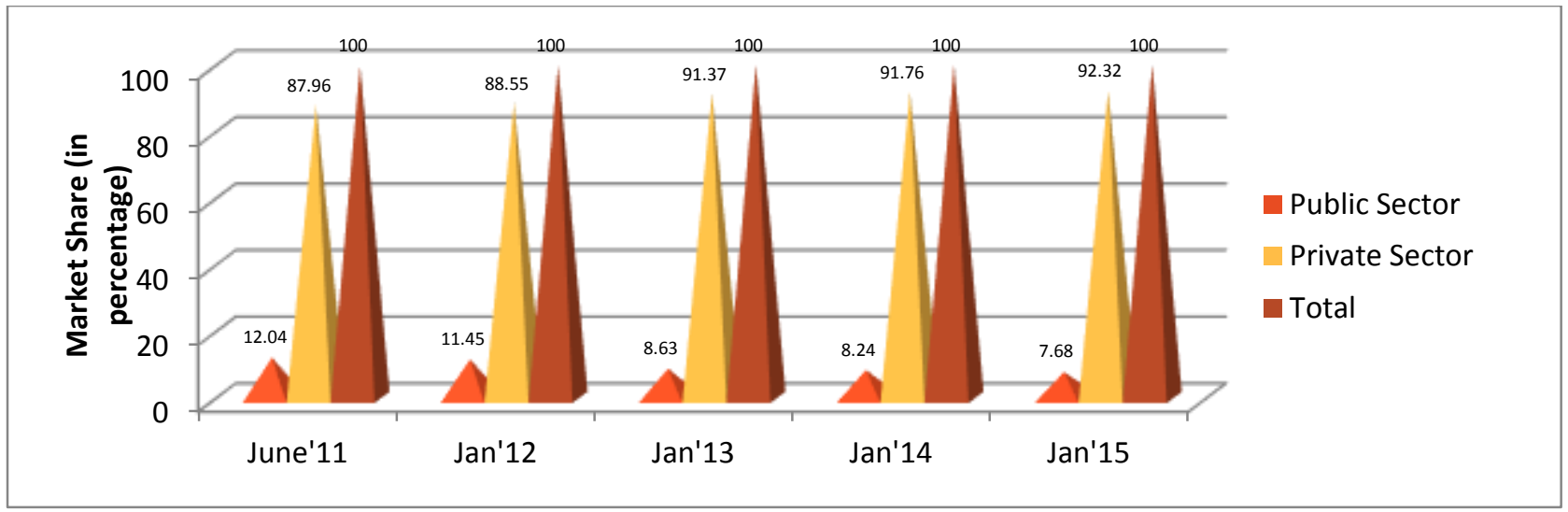

Fig. 1: Market Share of Public and Private Wireless Telecom Sector

Therefore, it is observed that last many years, Private sector is leading and moving ahead in the market of Assam Circle, while considered the performance of wireless subscribers' base.

As per as "Brand" is concerned as on Jan'2015, Bharti Airtel Limited is having maximum subscriber base and then followed by Dishnet Wireless (Aircel), Vodafone Spacetel, Reliance Telecom, BSNL and then Idea Cellular Limited.

\section{Market Share and position of Wireless Segment of Public and Private Telecom Sector in Assam Circle}

The Private Sector of Assam Telecom Circle has maximum market share over the last few years which may be due to the improvement in quality of service delivery, concerning for customers' feedback, increasing network coverage etc. From the Fig 1, it is observed that Private sector is leading in penetrating efficiently and effectively in the market of Assam Circle.

Private sector of Assam Telecom Circle has 87.96\%, $88.55 \%, 91.37 \%, 91.76 \%$ and $92.32 \%$ of market share in the years 2011, 2012, 2013, 2014 and 2015 respectively, which reflects that there is a rapid positive growth of Private sector in the Circle, whereas Public sector has $12.04 \%$, $11.45 \%, 8.63 \%, 8.24 \%$ and $7.68 \%$ respectively in these years. It gives a clear picture that the market share of Public sector is declining day by day in Assam Telecom Circle. As on the year 2014-2015, Bharti Airtel Limited has maximum market share, followed by Dishnet Wireless (AIRCEL) Limited, Vodafone Spacetel Limited, Reliance
Telecom Limited and then Bharat Sanchar Nigam Limited (BSNL), which is the only Public Sector Unit (PSU) in the circle. Idea Cellular Limited has very less market share till now, as it has entered the Assam Circle very recently. Therefore, Airtel is leading and BSNL is holding $5^{\text {th }}$ position in the circle (Fig. 1).

\section{Proportion of Visitor Location Register (VLR) subscribers in Assam Circle}

The proportion of VLR subscribers on the date of Peak VLR in Assam Circle is approximately $85.46 \%, 90.40 \%$, and $94.35 \%$ of the total wireless subscriber base in the month of January of the year 2013, 2014 and 2015 respectively, reported by the service providers.

Table 2: Proportion of VLR subscriber

\begin{tabular}{|l|l|l|l|}
\hline Sector & January'13 & January'14 & January'15 \\
\hline $\begin{array}{l}\text { Public } \\
\text { Sector }\end{array}$ & 71.40 & 81.05 & 82.97 \\
\hline $\begin{array}{l}\text { Private } \\
\text { Sector }\end{array}$ & 76.91 & 90.99 & 94.63 \\
\hline
\end{tabular}

Source: Press Release, TRAI 2013, 2014 and 2015

From the above Table 2, it is observed that the Private sector leads by having the higher proportion of VLR subscriber compare to the VLR subscriber proportion of Public sector for all these years in Assam Telecom Circle. For enhancing the proportion of VLR subscribers, private cellular service providers are moving ahead by focusing more towards providing better network coverage. 
Table 3: Gross Revenue of wireless segment of Public and Private Telecom sector in Assam Circle in the year 2014

\begin{tabular}{|c|c|c|c|c|c|c|c|c|c|c|}
\hline \multirow{2}{*}{$\begin{array}{l}\text { S1 No } \\
1 .\end{array}$} & \multirow{2}{*}{$\begin{array}{l}\text { Sector } \\
\text { Public Sector }\end{array}$} & \multirow{2}{*}{$\begin{array}{l}\text { Name of the company } \\
\text { Bharat Sanchar Nigam } \\
\text { Limited }\end{array}$} & \multicolumn{2}{|c|}{$\begin{array}{l}\text { Gross Revenue } \\
\text { (Rs in Crore) } \\
\text { January- } \\
\text { March'14 }\end{array}$} & \multicolumn{2}{|c|}{$\begin{array}{l}\text { Gross Revenue } \\
\text { (Rs in crore) } \\
\text { April-June'14 }\end{array}$} & \multicolumn{2}{|c|}{$\begin{array}{l}\text { Gross Revenue } \\
\text { (Rs in crore) } \\
\text { July- Sep'14 }\end{array}$} & \multicolumn{2}{|c|}{$\begin{array}{l}\text { Gross Revenue } \\
\text { (Rs in crore) } \\
\text { Oct- Dec'14 }\end{array}$} \\
\hline & & & 63.46 & 63.46 & 58.99 & 58.99 & 59.96 & 59.96 & 54.37 & 54.37 \\
\hline \multirow{6}{*}{2.} & \multirow{5}{*}{$\begin{array}{l}\text { Private } \\
\text { Sector }\end{array}$} & Bharti Airtel Limited & 257.51 & \multirow{5}{*}{697.46} & 273.00 & \multirow{5}{*}{717.8} & 268.40 & \multirow{5}{*}{704.85} & 298.28 & \multirow{5}{*}{753.4} \\
\hline & & Dishnet Wireless Limited & 168.93 & & 168.95 & & 169.21 & & 173.11 & \\
\hline & & Reliance Telecom Limited & 102.70 & & 99.24 & & 93.12 & & 96.08 & \\
\hline & & Vodafone Spacetel Limited & 142.60 & & 148.51 & & 146.37 & & 155.32 & \\
\hline & & Idea Cellular Limited & 25.72 & & 28.10 & & 27.75 & & 30.61 & \\
\hline & & & & 760.92 & & 776.79 & & 764.81 & & 807.77 \\
\hline
\end{tabular}

Source: Report of Financial and Economic Analysis Division, TRAI (2014)

\section{Gross Revenue Growths in the year 2014}

As per a report by Telecom Regulatory Authority of India, wireless telecom service providers of Assam Circle recorded the Gross revenue of Rs. 760.92 crore, Rs. 776.79 crore, Rs. 764.81 crore and Rs. 807.77 crore in the months from January to March, April to June, July to September and lastly October to December' respectively in the year 2014.

From the Table 3, it is observed that the gross revenue made by the private sector in the year 2014 is much better than that of public sector in the circle.

From the above graph it is observed that private wireless operators of Assam Circle have increased their revenue share and earned more Gross revenue than public sector in the year 2014. In this case, Bhart Airetel Limited earned maximum gross revenue, followed by Dishnet Wireless, Vodafone Spacetel, Reliance Telecom, BSNL and Idea Cellular Limited.

\section{Conclusion}

In this study it has been attempted to compare the public and private cellular service providers of Assam Telecom Circle. With the maturity of markets, increase in network coverage and existence of more competition in Assam Circle, has resulted in declining of tariffs, so accelerating the growth of subscriber base and so market share in the sector. Under these circumstances, all the service providers both public and private sector of the circle required to construct their corporate planning related to customers' need.

In the study it was reflected that during the last few years, most of the private telecom service providers have revealed better performance than public sector counterparts in Assam Telecom Circle. It can also be concluded that Private Service providers are proved to be more liked by the mobile users of the circle and BSNL, the only public sector unit of the circle is vanishing away from the minds of the people. It shows a clear indicator of better performance by the private telecom sector of Assam Circle as this sector is holding the top position in terms of subscriber base, market share, gross revenue etc. in the circle.

\section{Suggestions}

Among cellular service providers, private sector is preferred and opted more by the customers in Assam Telecom Circle. Shah (2008), explained that in recent years, due to the bad management in public sector and immense competition in Telecom Sector, the only public sector state owned BSNL has been losing revenue and market share heavily. Kumar and Uma (2013) explained that Private cellular operators are proved to be the favorites of mobile users. According to Chaudhary (2014) and Yadav (2014), it has been witnessed that major area of concern for any bank and Telecom Company is the customer service and customer satisfaction. Thus, just like private telecom service providers, it is the high time for the BSNL, the only Public sector telecom company of Assam Telecom Circle, to start concentrating on quality service delivery to customers according to their needs and requirements and thereby satisfying the customers. It is only possible for public sector cellular service provider to get better performance and face competition if they give importance to show higher interest towards customer feedback, regular follow-up, promoting efficient management and thereby gaining proper networks and higher productivity throughout the Assam Circle.

\section{References}

Annual Report 2013-2014, Department of Telecommunications, Ministry of Communications \& Information Technology, Government of India, New Delhi. Retrieved from: http://www.dot.gov.in/sites/default/.../AR\%20201314\%20English\%20(2)_1.p[Accessed on $2^{\text {nd }}$ November, 2014]

Chaudhary G (2014) Performance Comparison of Private Sector Banks with the Public Sector Banks in India. International Journal of Emerging Research in Management \& Technology. 3: 5-12.

Financial Report- Telecom Regulatory Authority of India, $\left(14^{\text {th }}\right.$ August, 2014). " Financial Data Pertaining To Gross Revenue, Adjusted Gross Revenue, License Fee \& Spectrum Charges in Respect of the Telecom Service Providers for the Quarter Ending June 2014 (Rs. in Crore ) of Financial Year 2014-15 Retrieved from: http://trai.gov.in/Content/Performance [Accessed on $5^{\text {th }}$ November, 2014] 
Goel C and Rekhi CB (2013) A Comparative Study of Selected Public Sector and Private Sector Banks in India. Journal of Business Management \& Social Science Researc. 2: 4656.

Joshi H (2014) Telecom: Enabling growth and serving the masses. Retrieved from: http://www.deloitte.com/assets/DcomIndia/Local\%20Assets/Documents/Thoughtwave /2014/Telecom_Enabling_growth_and_serving_the_mass es.pdf. [Accessed on $1^{\text {st }}$ November, 2014]

Kumar AC and Uma HR (2013) A Comparative study of Public and Private cellular service providers in Karnataka stateAn empirical study using factor analysis. International Journal of Marketing and Technology. 3: 233-238.

Shah N (2008) Critically Analyze the Customer Preference and Satisfaction Measurement in Indian Telecom Industry. Ph.D. dissertation. The Indian Institute of Planning and Management, Ahmadabad, India Retrived from: http://www.slideshare.net/guest377d84/telecom-sectorthesis [Accessed on $11^{\text {th }}$ October, 2014]

Telecom Regulatory Authority of India, (12 March 2014). "Highlights of Telecom Subscription Data as on $31^{\text {st }}$ January, 2014"(PDF). Press release. Retrieved from: http://www.trai.gov.in/WriteReadData/whatsNew/Docum ents/Press\%20Release\%20on\%20Telecom\%20Subscripti on\%20Data\%20as\%20on\%2031st\%20January,\%202014. pdf [Accessed on 23 ${ }^{\text {rd }}$ October, 2014]
Telecom Regulatory Authority of India, (15 March 2013). "Highlights of Telecom Subscription Data as on $31^{\text {st }}$ January, 2013"(PDF). Press release. Retrieved from: http://www.trai.gov.in/WriteReadData/WhatsNew/Docu ments/PR-TSD-Mar13.pdf [Accessed on 23 ${ }^{\text {rd }}$ October, 2014]

Telecom Regulatory Authority of India, (7 April 2012). "Highlights of Telecom Subscription Data as on $29^{\text {th }}$ February, 2012"(PDF). Press release. Retrieved from: http://www.trai.gov.in/.../PressRealease/.../InfoPressTelecom\%20Subscription [Accessed on $25^{\text {th }}$ October, 2014]

Vazifehdost H and Rahmani M (2013) The Relationship Between Teamwork, Role Ambiguity, Supervisor-Nurse And Well -being: Public Against Private Sector Nurse. International Journal of Research In Social Sciences, 3: 18-26.

Verma N, Rangnekar S and Barua MK (2012) Team Effectiveness in Indian Organizations. Delhi Business Review. 13: 4354.

Yadav HR (2014) A Comparative Study on Performance of Public Sector and Private Sector Telecommunications With reference to wireless Services in India. International Journal of Research. 1::535-544. 